\title{
Leaching of Atrazine in Commercial and Xerogel Formulations in Oxisol Using Bioassay and Chromatographic Methods ${ }^{1}$
}

\author{
Lixiviação do Herbicida Atrazina em Formulação Comercial e Formulação Xerogel em \\ Latossolo Vermelho Distroférrico
}

\author{
MARCHESAN, E.D.2, TREZZI, M.M.², VIDAL, R.A. ${ }^{3}$, DICK, D.P.ㄹ, and XAVIER, E. ${ }^{2}$
}

\begin{abstract}
Mobility of atrazine in soil has contributed to the detection of levels above the legal limit in surface water and groundwater in Europe and the United States. The use of new formulations can reduce or minimize the impacts caused by the intensive use of this herbicide in Brazil, mainly in regions with higher agricultural intensification. The objective of this study was to compare the leaching of a commercial formulation of atrazine (WG) with a controlled release formulation (xerogel) using bioassay and chromatographic methods of analysis. The experiment was a split plot randomized block design with four replications, in a $(2 \times 6)+1$ arrangement. The main formulations of atrazine (WG and xerogel) were allocated in the plots, and the herbicide concentrations (0, 3200, 3600, 4200, 5400 and $\left.8000 \mathrm{~g} \mathrm{ha}^{-1}\right)$, in the subplots. Leaching was determined comparatively by using bioassays with oat and chromatographic analysis. The results showed a greater concentration of the herbicide in the topsoil $(0-4 \mathrm{~cm})$ in the treatment with the xerogel formulation in comparison with the commercial formulation, which contradicts the results obtained with bioassays, probably because the amount of herbicide available for uptake by plants in the xerogel formulation is less than that available in the WG formulation.
\end{abstract}

Keywords: percolation, residual herbicides, persistence, chromatography, xerogel.

\begin{abstract}
RESUMO - A mobilidade da atrazina no solo tem contribuido para que niveis acima do limite permitido sejam frequentemente detectados em águas de superfície e subterrâneas na Europa $e$ nos Estados Unidos. O uso de formulações mais adequadas pode reduzir ou minimizar os impactos provocados pelo intenso uso desse herbicida no Brasil, principalmente em regiões com agricultura mais intensiva. O objetivo do presente trabalho foi comparar a lixiviação de uma formulação de atrazina comercial (WG) com uma formulação de liberação controlada (xerogel), através da análise por bioensaio e por método cromatográfico. O delineamento utilizado foi o de blocos ao acaso, em parcelas subdivididas, com quatro repetições, em um esquema $(2 \times 6)+1$. Nas parcelas principais foram locadas as formulações de atrazina (WG $e$ xerogel), e nas subparcelas, as concentrações dos herbicidas (0, 3200, 3600, 4200, 5400 e $8000 \mathrm{~g}$ de atrazina $\mathrm{ha}^{-1}$ ). A determinação da lixiviação foi efetuada de forma comparativa, através de bioensaios com aveia e análises cromatográficas. As análises cromatográficas demonstraram que na camada superficial do solo $(0 \mathrm{a} 4 \mathrm{~cm})$ ocorreu maior concentração de atrazina no tratamento com a formulação xerogel, em comparação à formulação comercial, resultado que contrasta com a análise realizada pelo bioensaio, provavelmente porque a quantidade de herbicida disponivel para absorção pelas plantas na formulação xerogel é inferior à disponivel na formulação WG.
\end{abstract}

Palavras-chave: percolação, herbicidas residuais, persistência, cromatografia, xerogel.

\footnotetext{
${ }^{1}$ Recebido para publicação em 15.08.2014 e aprovado em 30.01.2015.

${ }^{2}$ Universidade Tecnológica Federal do Paraná (UTFPR), Pato Branco-PR, Brasil, <elidanieli_marchesan@yahoo.com.br>; 3 Universidade Federal do Rio Grande do Sul (UFRGS), Porto Alegre-RS, Brasil.
} 


\section{INTRODUCTION}

Leaching or percolation of herbicides is the downward movement thereof through the soil matrix, with or without water. For this process to occur, the herbicide should be in the soil solution, free or adsorbed on fine particles. Leaching may increase the risk of water contamination depending on its intensity (Ferri et al., 2003). In soil, leaching is the main form of transport of volatile and watersoluble molecules, which accompany the flow of water in the soil profile. During this process, organic molecules can reach subsurface layers in the profile and in some cases, they may also reach groundwater (Monquero, 2008).

The major factors related to herbicides that affect their movement and influencing their leaching are: physical and chemical characteristics of the molecules, including solubility, octanol/water partition coefficient, distribution coefficient, adsorption capacity, formulation, additives and biological degradation. Other factors such as $\mathrm{pH}$, water content, persistence in soil, area slope, intensity of rainfall or irrigation and retention of herbicides by soil colloids also affect leaching (Arias-Estévez et al., 2008). The higher the retention of the herbicide by colloids in the soil, the lower the desorption and the amount leached (Inoue et al., 2003). The amount of leached herbicide is directly related to its solubility in water and to the amount dissolved in the soil solution. Also, the reactivity of a molecule is associated with its ionic or residual charges. A herbicide with residual positive charge in the soil solution tends to be strongly adsorbed on soil colloids, and is less subject to leaching (Ávila, 2009). In turn, a herbicide with residual negative charge is more susceptible to leaching.

Atrazine (2-chloro-4-ethylamino6isopropylamino-s-triazine) is an herbicide commonly used in areas of corn, sugarcane and sorghum crops (Brasil, 2014). Given its extensive use and high persistence, atrazine and its metabolites are frequently found in surface water and groundwater in various locations worldwide (Kolpin et al., 1995; Graymore et al., 2001; Arias-Estévez et al.,
2008), and its use was banned in several countries (European Comission, 2004).

Atrazine is soluble in water and some organic solvents such as ether, ketone, benzene, chloroform, ethanol and ethyl acetate. It is a weakly basic, polar compound. The acid or alkaline hydrolysis of atrazine generates its most abundant degradation product, hydroxyatrazine, whose solubility in water is substantially independent of the solution $\mathrm{pH}$, but increases greatly in solutions with a pH below 2.0 (Javaroni et al., 1999).

Controlled release herbicides have shown several advantages over conventional formulations, including greater safety to nontarget organisms, lower amount of pesticides applied and reduced potential for leaching (Fernändez-Përez et al., 2001). The method of controlling the release of substances is seen as a series of interrelated processes involving the synthesis of an inorganic network achieved by the mixture of alkoxides and water in the presence of a solvent and a catalyst, followed by hydrolysis, gelation, removal of organic waste and water from pores of the solid gel through treatment at low temperatures. The densification of the dry gel by thermal treatment results in a porous material called xerogel (Andrade \& Domingues, 2006). The sol-gel method favors the formulation of organic compounds and allows the controlled release of the organic active ingredient (Böttcher et al., 1998). The use of a system for herbicide application combined with carrier systems for controlled release may represent a measure to mitigate environmental impacts triggered by the intensive use of herbicides in Brazilian agriculture; it is interesting both from the ecological and the economic points of view (Ávila et al., 2009).

The main hypothesis of this study is that the use of the commercial formulation (COM) of atrazine results in greater leaching compared with the xerogel formulation. The objective was to determine the leaching of commercial and controlled release formulations (XER) in Oxisol. 


\section{MATERIAL AND METHODS}

Collection of soil samples for leaching assessment - A field experiment was conducted in the Experimental Area of the Federal Technological University of Paraná, Campus Pato Branco, Paraná State, in the municipality of Pato Branco, at the geographical coordinates $26^{\circ} \quad 07^{\prime} \mathrm{S}$ and $52041^{\prime} \mathrm{W}$. According to the Brazilian soil classification system (Embrapa, 2006), the soil is classified as Oxisol (Bhering et al., 2008), with the following composition: $55.7 \%$ clay, $3 \%$ sand, $41.3 \%$ silt. The climate is humid subtropical with hot summers (Cfa), according to Köppen.

The experiment was a split plot randomized block design with four replications in a $(2 \times 6)+1$ arrangement. The formulations of atrazine (commercial and xerogel) were allocated in the plots, and the atrazine concentrations $(0,3200,3600,4200$, 5400 and $8000 \mathrm{~g} \mathrm{ha}^{-1}$ ), in the subplots, with four hoed control plots. The commercial formulation of atrazine $(C O M)$, in water dispersible granule (WG), is called GENIUS ${ }^{\circledR}$. The xerogel formulation was prepared at the Institute of Chemistry of the Federal University of Rio Grande do Sul (Ávila et al., 2009). Subplots consisted of five rows of corn, spaced at $0.7 \mathrm{~m}, 7 \mathrm{~m}$ in length, for the commercial treatment $\left(24.5 \mathrm{~m}^{2}\right)$ and $3 \mathrm{~m}$ in length $\left(10.5 \mathrm{~m}^{2}\right)$ for the xerogel treatment. The useful area of each subplot consisted of the three central lines, disregarding $0.5 \mathrm{~m}$ from the ends of each row.

Herbicides were applied at preemergence, after sowing the crop. The hybrid (Pioneer 30R50H) was sown using a seed drill to obtain a density of 67,000 plants ha-1. Seeds were previously treated with thiamethoxam + fipronil + $\left(1.75+0.5 \mathrm{~g} \mathrm{~kg}^{-1}\right.$ seed). Fertilization was performed in the area according to crop requirements by chemical analysis of the soil, using 24, 60 and $60 \mathrm{~kg}$ ha-1 of $\mathrm{N}, \mathrm{P}_{2} \mathrm{O}_{5}$ and $\mathrm{K}_{2} \mathrm{O}$, respectively, with the formulation 8-20-20. For topdressing, $65 \mathrm{~kg}$ $\mathrm{N} \mathrm{ha}^{-1}$ were used in the form of urea, next to the row between $V_{2}$ and $V_{3}$ stages (Ritchie et al., 1993). At the time of topdressing, the insecticide methamidophos $(180 \mathrm{~g} / 100 \mathrm{~L}$ water) was applied 20 days after sowing.

The commercial formulation of atrazine was sprayed on the moist soil after sowing corn, with a $\mathrm{CO}_{2}$-pressurized backpack sprayer, with constant pressure and bars with five fan type spray nozzles 110.02, spaced at $0.50 \mathrm{~m}$, which sprayed a water volume of $200 \mathrm{~L} \mathrm{ha}^{-1}$. As the XER formulation is in powder and it is hard to dilute it in water for application in the plots, it was mixed with the soil of the experimental area, previously dried, ground and sieved, at a proportion of $2 \mathrm{~kg}$ per subplot, and homogeneously distributed. The XER concentration was $231.9 \mathrm{mg} \mathrm{g}^{-1}$. The amount of atrazine for each subplot was calculated according to its concentration, and its distribution in the subplots was performed manually.

Determination of atrazine leaching of commercial and xerogel formulations - The evaluation of leaching of atrazine formulations was carried out after collecting two soil samples per subplot in the field experiment, on the $25^{\text {th }}$ day after the application in the treatments corresponding to the level of $8000 \mathrm{~g}$ atrazine ha-1 of the commercial and xerogel formulations. Each sample was collected by burying a PVC pipe (25 $\mathrm{mm}$ in diameter and $25 \mathrm{~cm}$ in length) perpendicularly to the soil in the useful area of the subplot, until the end of the tube was on the level of the ground surface. Shortly after, the pipes were withdrawn, taking care not to disintegrate the soil samples, which were stored in styrofoam boxes. In the laboratory, samples were stored in a freezer at $-5 \circ \mathrm{C}$ until using them in the greenhouse bioassay and extraction of atrazine for chromatography.

Greenhouse bioassay - In the green house, the upper third of the PVC pipe was longitudinally cut out for the transplantation of white oat plants, the indicator species. The pipes contained soil to a maximum depth of $16 \mathrm{~cm}$. White oat plants were transplanted at a spacing of $2 \mathrm{~cm}$, with the final planting of 8 plants per PVC pipe.

For the bioassay, we evaluated toxicity to white oat plants. Phytotoxicity was assessed 
at $7,14,21,28$ and 35 days after transplanting (DAT). The assigned scores ranged from $0 \%$ no effect to $100 \%$ - lethal effect to the plants (Frans et al., 1986). The data obtained in the bioassay were converted to percentage relative to the control without atrazine.

Determination of atrazine in soil by chromatography - Soil samples were frozen in a freezer and thawed for 24 hours before extraction with methanol. Each sample taken with the PVC pipe was split into four subsamples, so that the first fraction corresponded to the layer between 0 and 4 $\mathrm{cm}$ deep, the second between 4 and $8 \mathrm{~cm}$, the third between 8 and $12 \mathrm{~cm}$, and the fourth fraction between 12 and $16 \mathrm{~cm}$ deep.

Next, the fractions were weighed and delumped. HPLC methanol $(99.9 \%)$ at a $2: 1$ ratio was added for each gram dry soil. Vials were weighed without the soil, only with soil, and with soil plus methanol. After weighing, fractions were placed into a sealed plastic container to prevent possible leakage. After manual stirring to homogenize the sample, the vials were placed in a horizontal shaker for 24 hours at $18{ }^{\circ} \mathrm{C}$ and speed of $180 \mathrm{~min}^{-1}$. Then, samples were centrifuged for 10 minutes at $3000 \mathrm{rpm}$, and shortly afterwards, the supernatant was filtered through filter paper and stored in a measuring cylinder.

After the volumes of extracts were recorded, they were stored in amber vials and then cooled. Samples were concentrated to 10 $\mathrm{mL}$, using a rotary evaporator, and then filtered through glass wool and anhydrous sodium sulfate. The column was assembled in the cylindrical segment of the funnel with approximately $1 \mathrm{~cm}$ glass wool, and anhydrous sodium sulfate was added. The inner walls of the vial were washed with approximately $2 \mathrm{~mL}$ HPLC methanol to remove residues of the sample; the same volume was also used to complete $10 \mathrm{~mL}$ in the measuring cylinder after filtering. The resulting content was transferred to amber glass vials previously labeled and then stored in a refrigerator.

\begin{tabular}{llll} 
Before chromatographic & \multicolumn{2}{c}{ analysis, } \\
samples were filtered again & through \\
CHROMAFIL $^{\circledR}$ & filter (Xtra PVDF & $45 / 25 \mathrm{~mm}$
\end{tabular}

diameter) and stored in vials suitable for use in the equipment. We used a Shimadzu gas chromatograph (GC/MS), VF-5ms column, 30 $\mathrm{m} \times 0.25 \mathrm{~mm}, 0.25 \mathrm{um}$, injector temperature of $250 \circ \mathrm{C}$, heating ramp of $70 \circ \mathrm{C}-10 \circ \mathrm{C} / \mathrm{min}$ until $220{ }^{\circ} \mathrm{C}$, with helium 6.0 as a carrier gas, with flow of $1.2 \mathrm{~mL} \mathrm{~min}^{-1}$ and retention time of 14.193 minutes.

To quantify the herbicide, two standard curves were constructed for atrazine, one for the concentration $0-350 \mu \mathrm{g} \mathrm{L}^{-1}$ and another for concentrations between 350 and $4000 \mu \mathrm{g}$ $\mathrm{L}^{-1}$ to cover the concentration range of samples in the vials. In chromatographic analysis, we quantified chromatographic peak areas of atrazine, with the software Galaxy. Subsequently, atrazine concentrations were estimated based on the areas obtained in the standard curves for atrazine.

Statistical analysis - Data of the bioassay and bioavailability were subjected to analysis of variance by the F-test. Means were compared by the DMS test at $5 \%$ probability of experimental error $(p \geq 0.05)$. Data of the chromatographic analysis were assessed by comparing the means by the DMS test at 5\% probability of experimental error $(p=0.05)$.

\section{RESULTS AND DISCUSSION}

Our working hypothesis was that the use of the commercial formulation of atrazine would result in greater leaching, compared with the xerogel formulation. The damage to white oat plants was significantly different between depth, period, and interactions formulation $\mathrm{x}$ evaluation period and depth $\mathrm{x}$ evaluation period. The interaction between period and depth was significant only at $10 \%$ probability.

We observed an increase in phytotoxicity over time. In general, the commercial formulation caused greater phytotoxicity to plants than the xerogel formulation (Figure 1A).

In the course of the period, there was a gradual increase in phytotoxicity, with the maximum toxicity at the surface soil layer (0 $2 \mathrm{~cm}$ depth). Also, there was a gradual reduction in phytotoxicity with increasing 
depth (Figure 1B), indicating smaller concentrations of atrazine in the deeper layers of the soil.

The commercial formulation of atrazine was more toxic to plants of oat at depths of 2 and $4 \mathrm{~cm}$. Indeed, differences in phytotoxicity between the formulations reached $30 \%$ at the lowest depth (Figure 1C). The higher phytotoxicity of the commercial formulation is probably due to its rapid release, compared with the xerogel formulation. Differences between formulations decreased with increasing depths, but only significantly at depths of 2, 4 and $10 \mathrm{~cm}$.
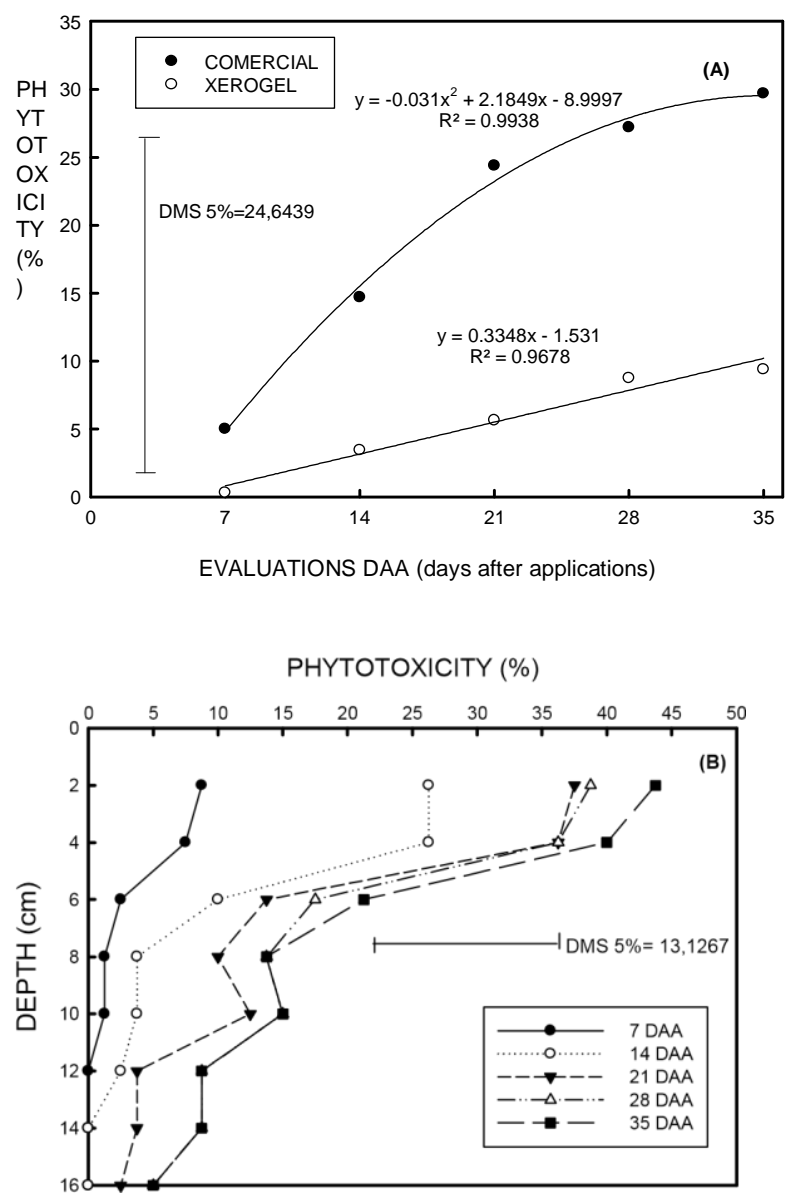

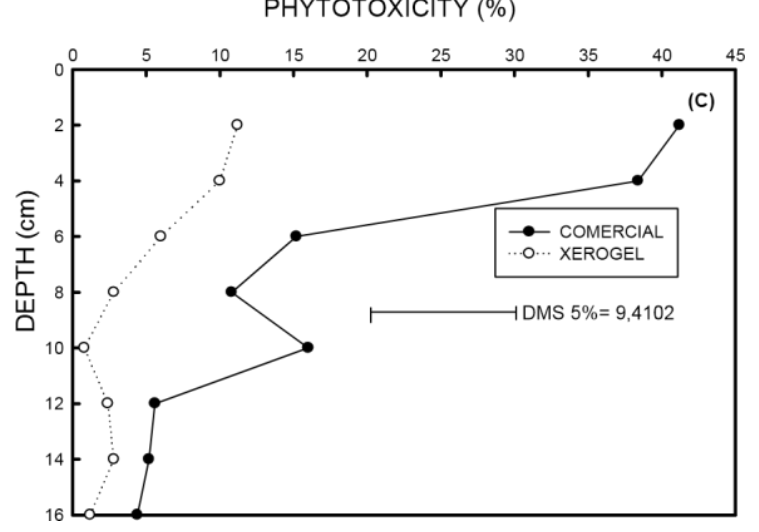

Figure 1 - (A) Toxicity of commercial and xerogel atrazine to oat plants according to the days of evaluation, on the average of depths. C.V. 74.56\%. (B) Toxicity of atrazine to oat according to the days of evaluation and depth, on the average of the commercial and xerogel formulations. (C) Toxicity of commercial and xerogel atrazine to oat at different depths, on the average of evaluation periods. $*$ Significant at $0.10 \%$.

The bioassay developed to assess the leaching of atrazine was efficient to detect the presence of the herbicide, as it showed differences in amounts of herbicide available for uptake by plants. Oat was also used to evaluate the efficiency and leaching in field and in laboratory of the herbicides atrazine and simazine (Stork, 1998).

Moreover, with the results of the bioassay, we found a greater availability of atrazine at depths of 2 and $4 \mathrm{~cm}$. However, the herbicide was detected up to approximately $14 \mathrm{~cm}$ depth with decreasing concentration with increasing soil depth. The greater phytotoxicity of atrazine in the commercial formulation, specifically at $10 \mathrm{~cm}$ depth, may be attributed to at least three causes. First, it may be associated with the upper preferential flow of the commercial formulation, derived from the greater availability of atrazine in the upper layers. Second, it may be related to the lower availability of nutrients to plants. Third, it may be due to greater soil compaction caused by the sampling method used, with effects occurring at random because there is no reasonable explanation for differences between formulations.

At the depth between 0 and $4 \mathrm{~cm}$, the concentration of xerogel atrazine extracted 
and determined chromatographically was $0.418 \mathrm{mg} \mathrm{kg}-1$, much higher than the commercial formulation, which showed only $0.101 \mathrm{mg} \mathrm{kg}^{-1}$ (Figure 2).

In the layer between 4 and $8 \mathrm{~cm}$, atrazine concentration in the commercial formulation was $0.021 \mathrm{mg} \mathrm{kg}^{-1}$ soil, whereas for the xerogel formulation, it was $0.00475 \mathrm{mg} \mathrm{kg}-1$ soil. For the third depth evaluated, between 8 and $12 \mathrm{~cm}$, atrazine concentration of the commercial formulation was $0.00275 \mathrm{mg} \mathrm{kg}^{-1}$ soil, and for the xerogel formulation, it was not detected. Absence of the herbicide was also registered at the depth $12-16 \mathrm{~cm}$ for both formulations.

This result is related to characteristics of the xerogel formulation that retains atrazine in a matrix, which determines its slow release into the soil. In turn, the release of commercial atrazine is more rapid. In this way, the commercial atrazine is more subject to transport and transformation in the soil, with

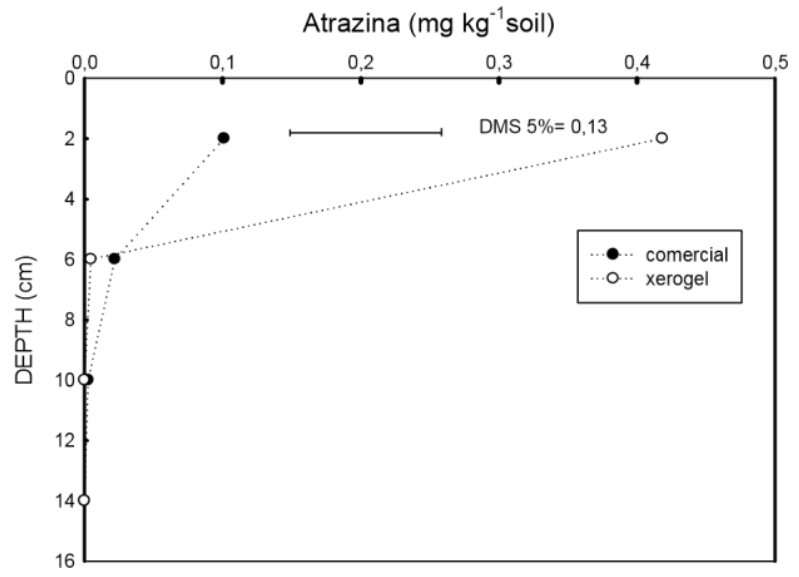

Figure 2 - Atrazine concentration desorbed with methanol of soil samples collected at 25 DAA.

a more rapid reduction in its concentration in the soil than xerogel atrazine, as observed in the surface layer, by chromatographic analysis.

In this context, herbicide leaching is affected by several factors operating together. It is frequently related to the preferential flow caused by cracks in the soil. Factors that determine the leaching potential of pesticides in soil include water solubility of the molecule, texture and structure of soil and rainfall in the region (Lavorenti et al., 2003). The soil in which this experiment was conducted (clay $55.7 \%$, sand $3.0 \%$, silt $41.3 \%$ and organic matter $49.59 \mathrm{~g} \mathrm{dm}^{-3}$ ) does not favor the leaching process of atrazine due to the high content of clay. Rainfall to the date of sampling at 25 DAA was $90 \mathrm{~mm}$. Nevertheless, clayey soils with higher content of organic matter allow higher adsorption, thus reducing the movement of atrazine. Furthermore, the permeability of the soil is positively correlated with leaching (Neurath et al., 2004).

After applied, atrazine may be lost through photochemical degradation, runoff and microbial degradation, which is the main form of degradation of this herbicide in soil (Kaufman \& Kearney, 1970). When a herbicide is strongly sorbed to the soil, there is low degradation, and as a result, this degradation is minimized by the attack of soil microorganisms. Similarly, less degradation of atrazine might occur when it is adsorbed onto the xerogel matrix.

Finally, at deeper layers, $4-8 \mathrm{~cm}$ and $8-$ $10 \mathrm{~cm}$, few differences were detected between formulations when analyzed by gas chromatography (Figure 2), although a greater inhibition of oat growth at these depths had been verified in the presence of commercial atrazine (Figure 1B). Thereby, the hypothesis of greater leaching of atrazine of the commercial formulation as compared with xerogel was confirmed only by using the oat bioassay. Reduction of leaching of atrazine is important, considering that this herbicide is a potential contaminant of water, because it has a high potential for runoff, high persistence in soil, slow hydrolysis, low to moderate water solubility, moderate adsorption to organic matter and clay (Ueta et al., 2004).

Our results allow concluding that when compared the formulations of atrazine, there are contradictory results between the bioassay and the determination of atrazine through gas chromatography.

The bioassay with oat detect a greater concentration of the commercial atrazine at the depth between 0 and $4 \mathrm{~cm}$, compared 
with the xerogel atrazine, while the chromatographic analysis indicated a greater concentration of xerogel at this depth.

Our results point out that although the xerogel formulation is present at higher concentrations in the layer up to $4 \mathrm{~cm}$ deep, it is available in the soil solution at a reduced concentration for uptake by plants.

\section{LITERATURE CITED}

ANDRADE, A. L.; DOMINGUES, R. Z. Cerâmicas bioativas: estado da arte. Química Nova, v. 29, n. 1, p. 100-104, 2006.

ARIAS-ESTÉVEZ, M. et al. The mobility and degradation of pesticides in soils and the pollution of groundwater resources. Agric. Ecosyst. Environ., v. 123, n. 4, p. 247-260, 2008.

ÁVILA, L. G. et al. Formulações de atrazina em xerogéis: síntese e caracterização. Química Nova, v. 32, n. 7, p. 1727-1733, 2009.

BHERING, S. B. et al. Mapa de solos do Estado do Paraná: legenda atualizada. Rio de Janeiro: EMBRAPA/ IAPAR, 2008. p.74.

BÖTTCHER, H.; SLOWIK, P.; SUB, W. Sol - Gel carrier systems for controlled drug delivery. Journal of Sol-gel Science Technology, v. 13, n. 1-3, p. 277-281, 1998.

BRASIL. Ministério da Agricultura, Pecuária e Abastecimento. Agrofit: sistema de agrotóxicos Fitossanitários. Disponível em: <http:// extranet.agricultura.gov.br/agrofit_cons/

principal_agrofit_cons>. Acesso em: 2 maio 2014.

EMPRESA BRASILEIRA DE PESQUISA AGROPECUÁRIA - EMBRAPA. Sistema brasileiro de classificação de solos. Rio de Janeiro: 2006. 412 p.

EUROPEAN COMISSION. Decision of 10 March 2004 (2004/248/EC), L78/53. Official Journal of European Union Comission, 2004.

FERNÁNDEZ-PÉREZ, M. et al. Bentonite and humic acid as modififying agentes in controlled release formulations of diuron and atrazine. Journal Environmental Quality, v. 29, n. 1, p. 304-310, 2000.

FERRI, M. et al. Lixiviação do herbicida acetoclor em solo submetido à semeadura direta e ao preparo convencional. Pestic. Revista de Ecotoxicologia e Meio Ambiente, v. 13, n. 1, p. 147-156, 2003.
FRANS, R. et al. Experimental design and techniques for measuring and analyzing plant responses to weed control practices. In: CAMPER, N. D. Research methods in weed science. Champaign: Weed Science, 1986. p. 29-46.

GRAYMORE, M.; STAGNITTI, F.; ALLISON, G. Impacts of atrazine in aquatic ecosystems. Environment International, v. 26, n. 7-8, p. 483-495, 2001.

INOUE, M. H. et al. Critérios para avaliação do potencial de lixiviação dos herbicidas comercializados no Estado do Paraná. Planta Daninha, v. 21, n. 2, p. 313-323, 2003.

JAVARONI, R. C. A.; LANDGRAF, M. D.; REZENDE, M. Comportamento dos herbicidas e alachlor em solo preparado para o cultivo de cana-de-açúcar. Química Nova, v. 22, n. 1, p. 58-64, 1999.

KAUFMAN, D. D.; KEARNEY, P. C. Microbial degradation of triazine herbicides. Residue Reviews, v. 32, p. 235-265, 1970.

KOPLIN, D. A.; GOOLSBY, D. A.; THURMAN, E. M. Pesticides in near-surface aquifers: An assessment using highly sensitive analytical methods and tritium. Journal of Environment Quality, v. 24, n. 6, p. 1125-1132, 1995.

LAVORENTI, A.; PRATA, F.; REGITANO, J. B.

Comportamento de pesticidas em solos: fundamentos. In: CURI, N.; MARQUES, J. J.; GUILHERME, L. R. G.; LIMA, J. M.; LOPES, A. S.; ALVAREZ V., V. H. (Org.). Tópicos especiais em ciência do solo. Viçosa, MG, Sociedade Brasileira de Ciência do Solo, 2003. v. 3. p. $335-400$.

MONQUERO, P. A. et al. Potencial de lixiviação de herbicidas no solo submetidos a diferentes simulações de precipitação. Planta Daninha, v. 26, n. 2, p. 403-409, 2008.

NEURATH, S. et al. Atrazine distribution measured in soil and leachate following infiltration conditions.

Chemosphere, v. 54, n. 4, p. 489-496, 2004.

RITCHIE, S. W. et al. How a corn plant develops. Ames: Iowa State University of Science and Technology, Cooperative Extension Service, 1993.

STORK, P. R. Bioefficacy and leaching of controlled-release formulations of triazine herbicides. Weed Research, v. 38, n. 6, p. 433-441, 1998.

UETA, J.; PEREIRA, N. L.; SHUHAMA, I. k. Biodegradação de herbicidas e biorremediação microrganismos degradadores do herbicida Atrazina. Jaguariúna: CNPMA/EMBRAPA, 2004. p. 10-13. 